\title{
HUBUNGAN STRATEGI KOPING DENGAN KUALITAS HIDUP PADA PASIEN GAGAL GINJAL KRONIK YANG MENJALANI HEMODIALISADI RSU IMELDA MEDAN
}

\author{
1. Deddy Sepadha Putra Sagala; ${ }^{2 .}$ Sri Marliana Pasaribu \\ 1. Dosen Prodi S-I Keperawatan, STIKes Imelda; ${ }^{2}$ Mahasiswi Prodi S-I Keperawatan STIKes Imelda \\ Jalan Bilal Nomor 52 Medan \\ E-mail: 1. $\underline{\text { deddyspsagala@gmail.com,; }{ }^{2} \text { srimarlianapsb@gmail.com }}$
}

\begin{abstract}
ABSTRAK
Gagal ginjal kronis merupakan suatu penyakit ginjal tahap akhir yang mengakibatkan gangguan fungsi ginjal yang bersifat irreversible dan menahun sehingga terjadinya penurunan kemampuan fungsi tubuh untuk mempertahankan metabolisme serta keseimbangan cairan dan elektrolit. Pasien gagal ginjal kronis akan mengalami kehilangan fungsi ginjal sampai $90 \%$ atau lebih, sehingga kemampuan tubuh untuk mempertahankan cairan dan elektorilit terganggu, sekresi menjadi tidak adequat dan fungsi hormonal terganggu sehingga mengakibatkan sindrom uremia atau azotemi (Rendy \& Margareth, 2012 ; Parson, Toffelmire \& Valack, 2006).Jenis penelitian ini kuantitatif menggunakan desain korelasional dengan jenis rancangan penelitian cross sectional. Dimana jumlah populasi sebanyak 98 responden, metodepengambilan sampel probability sampling tehnik accidental sampling sampel, besar sampel ditetapkan menggunakan rumus slovin didapati responden penelitian ini sebanyak 79penderita gagal ginjal kronik yang menjalani terapi hemodialisa di RSU Imelda Medan Tahun 2018.Pengumpulan data menggunakan Instrumen kualitas hidup World Health Organization Quality of Life-BREF (WHOQOL-BREF) dan Instrumen pengumpulan data strategi koping menggunakan kuesioner WCQ (Ways of Coping Questionare).Pengolahan data menggunakan analisa data univariat dan bivariatmenggunakan uji statistik parametrik yaitu uji pearson corelation (pearson product moment) dengan $p<0.05$, didapati hasil penelitian menunjukkan nilai probabilitas $(p)$ untuk strategi koping $=0,000$, yang berarti ada hubungan secara signifikan dengan kualitas hidup $(p<0.05)$. Hasil analisis diperoleh nilai correlation coefficient $(r)=0,733$, menunjukkan hubungan yang kuat dan berpola positif artinya semakin tinggi penggunaan strategi Problem Focused Coping (PFC) maka kualitas hidup yang dimiliki pasien gagal ginjal kronis yang menjalani hemodialisa semakin baik, Sedangkan hasil analisis diperoleh nilai correlation coefficient $(r)=-0,419$, menunjukkan hubungan yang sedang dan berpola negatif artinya semakin rendah penggunaan strategi Emotion Focused Coping (EFC) maka kualitas hidup yang dimiliki pasien gagal ginjal kronis yang menjalani hemodialisa semakin baik.
\end{abstract}

Kata kunci: Strategi koping, Kualitas hidup, gagal ginjal kronik, hemodialisa

\section{PENDAHULUAN}

Ginjal merupakan salah satu dari beberapa organ vital dalam tubuh yang berfungsi untuk menyaring racun dan zat - zat sisa dalam darah, menjaga keseimbangan volume dan komposisi cairan tubuh, serta menjaga konsentrasi elektrolit dan keseimbangan asam basa. Penderita gagal ginjal kronik (PGK) menurut estimasi World Health Organization (WHO, 2011) secara global lebih dari 500 juta orang dan sekitar 1,5 juta orang harus menjalani hemodialisis. Populasi penderita gagal ginjal di Indonesia dari tahun ke tahun semakin meningkat ((Rendy \& Margareth, 2012 ; Parson, Toffelmire \& Valack, 2006).

Berdasarkan Riset Kesehatan Nasional (Riskesnas, 2014), angka total menjadi 33,5\%. Berdasarkan data 7th Report of Indonesian Renal Registry tahun 2014 menunjukkan 56\% penderita penyakit ginjal adalah penduduk usia produktif dibawah 55 tahun.Hill et al, (2016)menyatakan bahwa prevalensi global PGK sebesar 13,4\%, sedangkan menurut Global Burden of Disease (2010), PGK merupakan penyebab kematian peringkat ke-27 
di dunia tahun 1990 dan meningkat menjadi urutan ke-18 pada tahun 2010. Son, et al, (2009) menunjukkan bahwa perawatan penyakit ginjal merupakan pembiayaan terbesar kedua yang menjadi tanggungan BPJS kesehatan di Indonesia setelah penyakit jantung.Salah satu terapi yang paling sering dilakukan oleh pasien penyakit ginjal kronik di seluruh dunia adalah hemodialisis.

Hemodialisis merupakan suatu proses terapi pengganti ginjal dengan menggunakan selaput membran semi permeabel yang berfungsi seperti nefron sehingga dapat mengeluarkan produk sisa metabolisme dan mengoreksi gangguan keseimbangan cairan dan elektrolit pada pasien gagal ginjal (Ignatavicius\&Workman,2009). Hemodialisis yang dilakukan oleh pasien dapat mempertahankan kelangsungan hidup sekaligus akan merubah pola hidup pasien. Perubahan ini mencakup diet pasien, tidur dan istirahat, penggunaan obat-obatan, dan aktivitas seharihari (Schatell\&Witten,2012).

Pasien yang menjalani hemodialisis juga rentan terhadap masalah emosional seperti stress yang berkaitan dengan pembatasan diet dan cairan, keterbatasanfisik, penyakit terkait, dan efek samping obat, serta ketergantungan terhadap dialisis akan berdampak terhadap menurunnya kualitas hidup pasien (Son, etal,2009).Menurut Ginieri-Coccosis et al (2008), penurunan kualitas hidup terjadi pada pasien yang menjalani hemodialisis dalam kurun waktu yang lama. Permasalahan yang dikeluhkan oleh pasien berkaitan dengan kesempatan beraktivitas, beban biaya yang dikeluarkan, beban pembatasan asupan cairan dan pelayanan yang diberikan oleh petugas medis.

Di Indonesia penatalaksanaan pada pasien gagal ginjal yang paling sering dilakukan adalah terapi pengganti.Terapi pengganti yang sering digunakan adalah hemodialisis, sebanyak $78 \%$ dibanding terapi pengganti lainnya (Pernefri, 2012). Terapi hemodialisis akan mencegah kematian meski demikian terapi ini tidak dapat menyembuhkan atau memulihkan penyakit dan tidak mampu mengimbangi hilangnya aktivitas metabolik atau endokrin yang dilakukan ginjal. Biasanya pasien akan menjalani terapi hemodialisis seumur hidup yang biasanya dilakukan sebanyak tiga kali seminggu selama 3-4 jam per kali terapi (Brunner \& Suddarth, 2008).

Rumah Sakit Umum Imelda Pekerja Indonesia (RSU IPI) merupakan rumah sakit tipe madya non pendidikan yang telah menjalankan unit hemodialisa sejak tahun 2010 dengan kapasitas 16 mesin hemodialisis. Berdasarkan data RSU Imelda Pekerja Indonesia Medan tahun 2017 jumlah kunjungan pasien hemodialisa per bulan rata - rata 352 orang secara reguler dengan jumlah alat hemodialisis sebanyak 16 buah. Hasil survey awal yang dilakukan di Unit Hemodialisa, bahwa pasien hemodialisa yang ada di RSU Imelda Pekerja Indonesia Medan terdapat 14 dari 48 pasien hemodialisa mengatakan bahwa mereka merasa pusing saat mengikuti proses hemodialisa. 12 dari 48 mengemukakan bahwa sering mengalami mual-mual, sesak nafas, dan sering bermasalah dengan AV Shunt, 13 dari 48 pasien mengatakan sering merasakan sakit berkepanjangan setelah ataupun sebelum hemodialisa sehingga tidak bisa melakukan aktivitas sehari-hari. 23 dari 48 pasien merasakan kadang-kadang merasakan khawatir mengenai kondisi.Hal ini menunjukkan belum adanya intervensi mandiri yang dilakukan oleh perawat.Biasanya untuk mengatasi masalah pasien hemodialisa diatas, perawat hanya dapat melaporkan ke dokter jaga dan mengalihkan perhatian pasien dengan mengajak pasien berkomunikasi sehingga untuk sementara waktu masalah yang dialami pasien bisa diminimalisir.

Berdasarkan fenomena tersebut sehingga peneliti tertarik mengambil judul "Hubungan strategi koping dengan kualitas hidup pada pasien gagal ginjal yang menjalani hemodialisa di RSU Imelda Medan Tahun 2018”. 


\section{Rumusan Masalahan}

Melihat latar belakang permasalahan yang didapat oleh peneliti maka yang menjadi permasalahan dalam penelitian ini adalah "Bagaimana hubungan strategi koping dengan kualitas hidup pada pasien gagal ginjal kronik yang menjalani hemodialisa di RSU Imelda Medan".

\section{Tujuan Penelitian}

1. Tujuan Umum

Penelitian ini bertujuan untuk mengetahui hubungan strategi koping dengan kualitas hidup pada pasien gagal ginjal kronik yang menjalani hemodialisa di RSU Imelda Medan

2. Tujuan Khusus

1. Mengetahui strategi koping pasien gagal ginjal kronik yang menjalani hemodialisis di RSU

\section{Imelda Medan}

2. Mengetahui kualitas hidup pasien gagal ginjal kronik yang menjalani hemodialisis di RSU Imelda Medan

3. Mengetahui hubungan strategi koping dengan kualitas hidup pasien gagal ginjal kronik yang menjalani hemodialisis di RSU Imelda Medan

\section{Hipotesis}

Hipotesis yang diajukan dalam penelitian ini adalah :Ada hubungan strategi koping dengan kualitas hidup pasien gagal ginjal

HASIL

Tabel 1. Karakteristik Responden

\begin{tabular}{|c|c|c|c|c|c|c|}
\hline \multirow[t]{2}{*}{ No } & \multirow[t]{2}{*}{ Karakteristik } & \multirow[t]{2}{*}{$\mathbf{F}$} & \multirow{2}{*}{$\begin{array}{l}\text { Persentase } \\
(\%)\end{array}$} & \multicolumn{3}{|c|}{ Kualitas Hidup } \\
\hline & & & & $\begin{array}{l}\text { Baik } \\
(\%)\end{array}$ & $\begin{array}{l}\text { Cukup } \\
(\%)\end{array}$ & $\begin{array}{l}\text { Buruk } \\
(\%)\end{array}$ \\
\hline 1. & Usia (Tahun) & & & & & \\
\hline & 26-44 (usia dewasa) & 9 & 11,4 & $\begin{array}{c}2 \\
(22,2)\end{array}$ & $\begin{array}{c}5 \\
(55,6)\end{array}$ & $\begin{array}{c}2 \\
(22,2)\end{array}$ \\
\hline & 45-59 (usia pertengahan) & 48 & 60,8 & $\begin{array}{c}14 \\
(29,2)\end{array}$ & $\begin{array}{c}27 \\
(56,2)\end{array}$ & $\begin{array}{c}7 \\
(14,6)\end{array}$ \\
\hline & 60-74 (lanjut usia) & 22 & 27,8 & $\begin{array}{c}4 \\
(18,2) \\
\end{array}$ & $\begin{array}{c}12 \\
(54,5) \\
\end{array}$ & $\begin{array}{c}6 \\
(27,3) \\
\end{array}$ \\
\hline
\end{tabular}

kronik yang menjalani hemodialisis di RSU Imelda Pekerja Indonesia.

\section{METODE}

Jenis penelitian ini merupakan penelitian kuantitatif menggunakan desain korelasional dengan jenis rancangan penelitian cross sectional. Pada penelitian ini bertujuan untuk menganalisis hubungan antara variabel independen yaitu strategi koping dengan variabel dependen yaitu kualitas hidup pada penderita gagal ginjal kronik yang menjalani terapi hemodialisa yang di ukur dalam satukali pengukuran dengan menggunakan kuesioner.Populasi dalam penelitian ini adalah seluruh penderita gagal ginjal kronik yang menjalani terapi hemodialisa berjumlah 98 orang di Rumah Sakit Umum Imelda Medan.Teknik sampling yang digunakan dalam penelitian ini dengan menggunakan metode purposive sampling. Untuk menentukan besar sampel yang akan diteliti, peneliti menggunakan rumus sampel untuk penelitian korelasi dengan menggunakan rumus Slovin (1996). Kuesioner yang digunakan untuk mengukur startegi koping yaitu kuesioner yang sudah dimodifikasi dari WCQ (Ways of Coping Questionare).Instrumen pengumpulan data kualitas hidup dikumpulkan dengan menggunakan kuisioner World Health Organization Quality of Life-BREF (WHOQOL-BREF).Uji statistik parametrik yang digunakan yaitu uji pearson corelation (pearson product moment). Dengan uji normalitas Kolmogrov-Smirnov. 


\begin{tabular}{|c|c|c|c|c|c|c|}
\hline & Laki-laki & 25 & 31,6 & $\begin{array}{c}9 \\
(36,0)\end{array}$ & $\begin{array}{c}13 \\
(52,0)\end{array}$ & $\begin{array}{c}3 \\
(12,0)\end{array}$ \\
\hline & Perempuan & 54 & 68,4 & $\begin{array}{c}11 \\
(20,4)\end{array}$ & $\begin{array}{c}31 \\
(57,4)\end{array}$ & $\begin{array}{c}12 \\
(22,2) \\
\end{array}$ \\
\hline \multirow{5}{*}{3.} & Pendidikan & & & & & \\
\hline & SD & 22 & 27,8 & $\begin{array}{c}2 \\
(9,0)\end{array}$ & $\begin{array}{c}10 \\
(45,5)\end{array}$ & $\begin{array}{c}10 \\
(45,5)\end{array}$ \\
\hline & SMP & 18 & 22,8 & $\begin{array}{c}5 \\
(27,8)\end{array}$ & $\begin{array}{c}12 \\
(66,7)\end{array}$ & $\begin{array}{c}1 \\
(5,6)\end{array}$ \\
\hline & SMA & 36 & 45,6 & $\begin{array}{c}11 \\
(30,6) \\
\end{array}$ & $\begin{array}{c}21 \\
(58,3) \\
\end{array}$ & $\begin{array}{c}4 \\
(11,1) \\
\end{array}$ \\
\hline & PT & 3 & 3,8 & $\begin{array}{c}2 \\
(66,7)\end{array}$ & $\begin{array}{c}1 \\
(33,3)\end{array}$ & $\begin{array}{c}0 \\
(0)\end{array}$ \\
\hline \multirow[t]{4}{*}{4.} & Status Pernikahan & & & & & \\
\hline & Menikah & 59 & 74,7 & $\begin{array}{c}18 \\
(30,5) \\
\end{array}$ & $\begin{array}{c}33 \\
(55,9) \\
\end{array}$ & $\begin{array}{c}8 \\
(13,6) \\
\end{array}$ \\
\hline & Janda/Duda & 16 & 20,3 & $\begin{array}{c}2 \\
(12,5)\end{array}$ & $\begin{array}{c}7 \\
(43,8)\end{array}$ & $\begin{array}{c}7 \\
(43,8) \\
\end{array}$ \\
\hline & Belum Menikah & 4 & 5,1 & $\begin{array}{c}0 \\
(0)\end{array}$ & $\begin{array}{c}4 \\
(100)\end{array}$ & $\begin{array}{c}0 \\
(0)\end{array}$ \\
\hline \multirow[t]{4}{*}{5.} & Suku Bangsa & 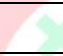 & 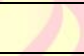 & & & \\
\hline & Batak & 41 & 51,9 & $\begin{array}{c}9 \\
(22,0)\end{array}$ & $\begin{array}{c}22 \\
(53,7)\end{array}$ & $\begin{array}{c}10 \\
(24,4) \\
\end{array}$ \\
\hline & Jawa & 32 & 40,5 & $\begin{array}{c}9 \\
(28,1)\end{array}$ & $\begin{array}{c}19 \\
(59,4)\end{array}$ & $\begin{array}{c}4 \\
(12,5)\end{array}$ \\
\hline & Melayu & 6 & 7,6 & $\begin{array}{c}2 \\
(33,3)\end{array}$ & $\begin{array}{c}3 \\
(50,0)\end{array}$ & $\begin{array}{c}1 \\
(16,7)\end{array}$ \\
\hline \multirow[t]{3}{*}{6.} & Status Pekerjaan & & & $\sqrt{1}$ & & \\
\hline & Bekerja & 36 & 45,6 & $\begin{array}{c}12 \\
(33,3)\end{array}$ & $\begin{array}{c}18 \\
(50,0)\end{array}$ & $\begin{array}{c}6 \\
(16,7)\end{array}$ \\
\hline & Tidak bekerja & 43 & 54,4 & $\begin{array}{c}8 \\
(18,6)\end{array}$ & $\begin{array}{c}26 \\
(60,5)\end{array}$ & $\begin{array}{c}9 \\
(20,9) \\
\end{array}$ \\
\hline \multirow[t]{3}{*}{7.} & Penghasilan Keluarga & & & 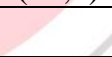 & & \\
\hline & $\leq \mathrm{Rp} 2.750 .000(\leq \mathrm{UMK})$ & 66 & 83,5 & $\begin{array}{c}15 \\
(22,7) \\
\end{array}$ & $\begin{array}{c}36 \\
(54,6) \\
\end{array}$ & $\begin{array}{c}15 \\
(22,7) \\
\end{array}$ \\
\hline & $>\operatorname{Rp} 2.750 .000$ (>UMK) & 13 & 16,5 & $\begin{array}{c}5 \\
(38,5)\end{array}$ & $\begin{array}{c}8 \\
(61,5)\end{array}$ & $\begin{array}{c}0 \\
(0)\end{array}$ \\
\hline \multirow[t]{3}{*}{8.} & Biaya Pengobatan & & & & & \\
\hline & BPJS & 76 & 96,2 & $\begin{array}{c}19 \\
(25,0)\end{array}$ & $\begin{array}{c}42 \\
(55,3)\end{array}$ & $\begin{array}{c}15 \\
(19,7)\end{array}$ \\
\hline & Asuransi Lain & 3 & 3,8 & $\begin{array}{c}1 \\
(33,3)\end{array}$ & $\begin{array}{c}2 \\
(66,7)\end{array}$ & $0(0)$ \\
\hline \multirow[t]{3}{*}{9.} & $\begin{array}{l}\text { Lama Menjalani } \\
\text { Hemodialisa }\end{array}$ & & & & & \\
\hline & 3-6 Bulan & 56 & 70,9 & $\begin{array}{c}14 \\
(25,0) \\
\end{array}$ & $\begin{array}{c}30 \\
(53,6) \\
\end{array}$ & $\begin{array}{c}12 \\
(21,4) \\
\end{array}$ \\
\hline & $>6-12$ Bulan & 23 & 29,1 & $\begin{array}{c}6 \\
(26,1) \\
\end{array}$ & $\begin{array}{c}14 \\
(60,9)\end{array}$ & $\begin{array}{c}3 \\
(13,0) \\
\end{array}$ \\
\hline \multirow[t]{2}{*}{10.} & Siklus Hemodialisa & & & & & \\
\hline & $2 \mathrm{X}$ perminggu & 55 & 69,7 & $\begin{array}{c}15 \\
(27,2)\end{array}$ & $\begin{array}{c}31 \\
(56,4) \\
\end{array}$ & $\begin{array}{c}9 \\
(16,4) \\
\end{array}$ \\
\hline
\end{tabular}




\begin{tabular}{lccccc}
\hline 3X perminggu & 22 & 27,8 & 4 & 12 & 6 \\
& & & $(18,2)$ & $(54,5)$ & $(27,3)$ \\
\hline 4X perminggu & 2 & 2,5 & $\begin{array}{c}1 \\
(50,0)\end{array}$ & $\begin{array}{c}1 \\
(50,0)\end{array}$ & $0(0)$ \\
\hline Total & 79 & 100 & 20 & 44 & 15 \\
& & & $(25,3)$ & $(55,7)$ & $(19,0)$ \\
\hline
\end{tabular}

Menurut asumsi peneliti motivasi responden dalam kategori sedang dengan kualitas hidup yang cukup dikaitkan dengan karakteristik responden usia rata-rata responden mayoritas 45-59 (usia pertengahan) 48 responden $(60,8 \%)$, Hal ini sejalan dengan penelitian Desitasari (2014) didapatkan responden yang menderita penyakit gagal ginjal kronik yang banyak dari usia 40-60. Alam dan Hadibroto (2007) menyatakan bahwa semakin bertambahnya usia, fungsi ginjal juga akan menurun. Setelah umur 40 tahun akan terjadi kehilangan beberapa nefron. Setiap dekade pertambahan umur, fungsi ginjal menurun sekitar $10 \mathrm{ml} /$ menit/1,73 m2. Selain karena penurunan fungsi ginjal organ tubuh oleh pertambahan usia, hal ini juga dapat disebabkan oleh beragam penyakit yang muncul di usia lanjut yang menimbulkan komplikasi pada sistem urinaris (Katzung, 2002).

Berdasarkan tingkat pendidikan responden PT hanya 3 responden $(3,8 \%)$ Hal ini sejalan dengan penelitian Ismail, Hasanuddin dan Bahar (2011) yang menunjukkan bahwa mayoritas responden berpendidikan Menengah (SMP dan SMA) yaitu sebanyak 68,6\%. Penderita gagal ginjal kronik yang memiliki pendidikan yang tinggi akan mempunyai pengetahuan yang luas. Hal ini memungkinkan penderita untuk dapat mengontrol dirinya dalam mengatasi masalah yang dihadapi, mempunyai rasapercaya diri yang tinggi, berpengalaman, dan mempunyai perkiraan yang tepat untuk mengatasi kejadian, mudah mengerti tentang apa yang dianjurkan oleh petugas kesehatan (Yuliaw, 2009). Individu yang berpendidikan sarjana, perilakunya akan berbeda dengan individu yang berpendidikan SD. Niven (2012) menyatakan pendidikan pasien dapat meningkatkan kepatuhan, sepanjang pendidikan tersebut merupakan pendidikan yang aktif.

\section{Variabel Strategi Koping}

Hasil analisis penelitian pada 79 pasien gagal ginjal kronis yang menjalani hemodialisa berdasarkan analisis data strategi koping (Problem Focused Coping /PFC dan Emotion Focused Coping/EFC) terdapat pada tabel 4.2.

Tabel 2. Nilai Mean dan Standar Deviasi dari Data Strategi Koping yang Digunakan Pasien Gagal Ginjal Kronis yang Menjalani Hemodialisa di RSU Imelda Pekerja Indonesia Medan Tahun 2018 ( $\mathrm{n}=79)$

\begin{tabular}{ll}
\hline \multicolumn{1}{c}{ Strategi Koping } & Nilai \\
\hline Problem Focused Coping (PFC) & \\
\hline Mean & 43,38 \\
Standar deviasi & 7,73 \\
\hline Emotion Focused Coping(EFC) & \\
\hline Mean & 39,00 \\
Standar deviasi & 7,77 \\
\hline
\end{tabular}

Tabel 2. menunjukkan bahwa dari yang digunakan 79 pasien gagal ginjal kronis yang menjalani hemodialisa memiliki nilai mean 43,38 dengan standar deviasi 7,73, sehingga dapat disimpulkan kategori Problem Focused Coping (PFC) berdasarkan nilai mean dan standar deviasi adalah skor < 35,65 untuk Problem Focused Coping (PFC) rendah, skor 35,65-51,11 untuk Problem Focused Coping (PFC) sedang, dan skor $>51,11$ untuk Problem Focused Coping (PFC) tinggi. Nilai mean 39,00 dengan standar deviasi 7,77, sehingga dapat disimpulkan kategori Emotion Focused Coping (EFC) berdasarkan nilai mean dan standar deviasi adalah skor < 31,23 untuk Emotion Focused Coping (EFC) rendah, skor 31,23-47,77 untuk Emotion Focused Coping 
(EFC) sedang, dan skor > 47,77 untuk Emotion Focused Coping (EFC) tinggi.

Tabel 3. Distribusi Frekuensi Strategi Koping dengan Kualitas Hidup di RSU Imelda Pekerja Indonesia Medan Tahun 2018 ( $\mathrm{n}=79$ )

\begin{tabular}{|c|c|c|c|c|c|}
\hline $\begin{array}{l}\text { Strateg } \\
\text { i }\end{array}$ & $\mathbf{f}$ & $\begin{array}{l}\text { Persentas } \\
\text { e (\%) }\end{array}$ & Kualit & as Hidup & \\
\hline Koping & & & $\begin{array}{l}\text { Baik } \\
(\%)\end{array}$ & $\begin{array}{c}\text { Cukup } \\
(\%)\end{array}$ & $\begin{array}{c}\text { Buruk } \\
(\%)\end{array}$ \\
\hline \multicolumn{6}{|c|}{ Problem Focused Coping (PFC) } \\
\hline Tinggi & $\begin{array}{l}2 \\
3\end{array}$ & 29,1 & $\begin{array}{c}19 \\
(82,6)\end{array}$ & $\begin{array}{c}4 \\
(17,4)\end{array}$ & $\begin{array}{c}0 \\
0 \\
(0)\end{array}$ \\
\hline Sedang & $\begin{array}{l}4 \\
4 \\
\end{array}$ & 56,7 & $\begin{array}{c}1 \\
(2,3) \\
\end{array}$ & $\begin{array}{c}39 \\
(88,6) \\
\end{array}$ & $\begin{array}{c}4 \\
(9,1) \\
\end{array}$ \\
\hline Rendah & $\begin{array}{l}1 \\
2\end{array}$ & 15,2 & $\begin{array}{c}0 \\
(0)\end{array}$ & $\begin{array}{c}1 \\
(8,3)\end{array}$ & $\begin{array}{c}11 \\
(91,7)\end{array}$ \\
\hline Total & $\begin{array}{l}7 \\
9\end{array}$ & 100 & $\begin{array}{c}20 \\
(25,3)\end{array}$ & $\begin{array}{c}44 \\
(55,7)\end{array}$ & $\begin{array}{c}15 \\
(19,0)\end{array}$ \\
\hline \multicolumn{6}{|c|}{ Emotion Focused Coping (EFC) } \\
\hline Tinggi & $\begin{array}{l}1 \\
6\end{array}$ & 20,3 & $0(0)$ & $\begin{array}{c}13(81,4 \\
)\end{array}$ & $3(18,6)$ \\
\hline Sedang & $\begin{array}{l}3 \\
6 \\
\end{array}$ & 45,6 & $7(19,4)$ & $\begin{array}{c}18(50,0 \\
)\end{array}$ & $\begin{array}{c}11(30,6 \\
)\end{array}$ \\
\hline Rendah & $\begin{array}{l}2 \\
7\end{array}$ & 34,2 & $\begin{array}{c}13(48,1 \\
)\end{array}$ & $\begin{array}{c}13(48,1 \\
)\end{array}$ & $1(3,8)$ \\
\hline Total & $\begin{array}{l}7 \\
9\end{array}$ & 100 & $\begin{array}{c}20(25,3 \\
)\end{array}$ & $\begin{array}{c}44(55,7 \\
)\end{array}$ & $\begin{array}{c}15(19,0 \\
)\end{array}$ \\
\hline
\end{tabular}

Dukungan dari semua anggota keluarga terutama pasangan sangat berperan dalam pengambilan keputusan dan strategi ketahanan hidup dalam mengelola emosional (dukungan emosional); memberikan inspirasi \& motivasi dukungan penilaian); memberikan dukangan informasi tentang kesehatan, gaya hidup, diet; dukungan spiritual dan juga mendukung penyediaan fasilitas (dukungan instrumental) sangat membantu bagi penderita gagal ginjal kronik yang sedang menjalani pengobatan dan akan membantu untuk meningkatkan kualitas hidup pasien GGK (Muhamad, Afshari, \& Kazilan, 2011).

Menurut Lazarus dan Folkman dalam Sarafino dan Smith (2011), menyatakan bahwa individu cenderung menggunakan strategi Problem Focused Coping (PFC) ketika mereka percaya bahwa tuntutan dari situasi atau stressor dapat diubah, sedangkan penggunaan strategi Emotion Focused Coping (EFC) ketika mereka percaya hanya sedikit atau tidak dapat melakukan perubahan dari situasi tekanan, walaupun dalam situasi yang penuh tekanan, umumnya individu menggunakan kombinasi koping berfokus pada masalah dan strategi koping berfokus pada emosi.

Strategi koping yang efektif dalam menghadapi penyakit kronis seperti GGK ditambah selama masa pengobatan seperti hemodialisaakan sangat mempengaruhi kepatuhan pasien dalam melakukan terapi yang rutin dan timbulnya gejala fisik dan psikologis. Senada dengan hasil penelitian Yahaya, Subramanian, Bustam, dan Taib (2015), menemukan bahwa strategi Emotion Focused Coping (EFC) yang tinggi akan meningkatkan gejala physical and psychological distress, sedangkan pada responden dengan penggunaan strategi Problem Focused Coping (PFC) yang tinggi akan menurunkan gejala distress yang dilakukan pada pasien GGK yang menjalani terapi.

\section{Variabel Kualitas Hidup}

Hasil analisis penelitian pada 79 pasien gagal ginjal kronis yang menjalani hemodialisa berdasarkan analisis data kualitas hidup terdapat pada tabel 4.4 .

Tabel 4. Nilai Mean dan Standar Deviasi dari Data Kualitas Hidup yang Dimiliki Pasien Gagal Ginjal Kronis yang Menjalani Hemodialisa di RSU Imelda Pekerja Indonesia Medan Tahun 2018 ( $\mathrm{n}=79)$

\begin{tabular}{lc}
\hline \multicolumn{1}{c}{ Kualitas Hidup } & Nilai \\
\hline Mean & 75,34 \\
Standar deviasi & 15,0 \\
\hline
\end{tabular}

Tabel 4. menunjukkan bahwa dari kualitas hidup yang dimiliki 79 pasien gagal ginjal kronis yang menjalani hemodialisa memiliki nilai mean 75,34 dengan standar deviasi 15,0, sehingga dapat disimpulkan kategori kualitas hidup berdasarkan nilai mean dan standar deviasi adalah skor $<60,34$ untuk kualitas hidup buruk, skor 60,34-90,34 untuk kualitas hidup cukup, dan skor $>90,34$ untuk kualitas hidup tinggi. 
Tahap selanjutnya adalah analisis berdasarkan kategori kualitas hidup dengan pada 79 pasien gagal ginjal kronis yang menjalani hemodialisa terdapat pada tabel 4.5.

Tabel 5. Distribusi Frekuensi Kualitas Hidup di RSU Imelda Pekerja Indonesia Medan Tahun $2018(\mathrm{n}=79)$

\begin{tabular}{ccc}
\hline Kualitas Hidup & F & Persentase (\%) \\
\hline Baik & 20 & 25,3 \\
\hline Cukup & 44 & 55,7 \\
\hline Buruk & 15 & 19,0 \\
\hline Total & 79 & 100 \\
\hline
\end{tabular}

Menurut Sathvik, parthasarathi, Narahari \& Gurudev (2008), kualitas hidup menjadi ukuran penting setelah pasien menjalani terapi penggantian ginjal seperti hemodialisis atau transplantasi ginjal. Kualitas hidup pasien yang menjalani hemodialisis semakin menurun karena pasien tidak hanya menghadapi masalah kesehatan yang terkait dengan penyakit ginjal kronik tetapi juga terkait dengan terapi yang berlangsung seumur hidup, akibatnya kualitas hidup pasien yang menjalani hemodialisis lebih menurun (Mittal, S.K., Ahern, L., Flaster, E., Maesaka, J.K., \& Fishbane, S., 2001). Cleary(2005)

\section{Analisis Bivariat}

Berdasarkan hasil uji normalitas dengan menggunakan perbandingan nilai skewness dan standar error menghasilkan skor < 2 dan Kolmogrov Smirnov Test menghasilkan $p>0,05$ yang berarti distribusi data variabel strategi Problem Focused Coping (PFC) dan Emotion Focused Coping (EFC), dan kualitas hidup berdistribusi normal, sehingga uji statistik pada analisis bivariat yang digunakan yaitu uji pearson corelation (pearson product moment).

\section{Hubungan Strategi Koping dengan Kualitas Hidup}

Hasil uji statistik untuk hubungan strategi koping dengan kualitas hidup di RSU Imelda Pekerja Indonesia Medan. Hasil penelitian pada 79 pasien gagal ginjal kronis yang menjalani hemodialisa berdasarkan uji pearson corelation terdapat pada tabel 4.6
Tabel 6. Hasil Uji Pearson Corelation Strategi Koping dengan Kualitas Hidup di RSU Imelda Pekerja Indonesia Medan Tahun 2018 (n=79)

\begin{tabular}{ccc}
\hline Variabel & \multicolumn{2}{c}{ Kualitas Hidup } \\
\cline { 2 - 3 } & $\mathbf{r}$ & $\boldsymbol{p}$ \\
\hline $\begin{array}{c}\text { Strategi Problem Focused } \\
\text { Coping (PFC) }\end{array}$ & 0,733 & 0,000 \\
\hline $\begin{array}{c}\text { Strategi Emotion Focused } \\
\text { Coping (EFC) }\end{array}$ & $-0,419$ & 0,000 \\
\hline
\end{tabular}

Tabel 6. menunjukkan nilai probabilitas ( $p$ ) untuk strategi koping $=0,000$, yang berarti ada hubungan secara signifikan dengan kualitas hidup $(p<0.05)$. Hasil analisis diperoleh nilai correlation coefficient $(\mathrm{r})=0,733$, menunjukkan hubungan yang kuat dan berpola positif artinya semakin tinggi penggunaan strategi Problem Focused Coping (PFC) maka kualitas hidup yang dimiliki pasien gagal ginjal kronis yang menjalani hemodialisa semakin baik, Sedangkan hasil analisis diperoleh nilai correlation coefficient (r) $=-0,419$, menunjukkan hubungan yang sedang dan berpola negatif artinya semakin rendah penggunaan strategi Emotion Focused Coping (EFC) maka kualitas hidup yang dimiliki pasien gagal ginjal kronis yang menjalani hemodialisa semakin baik

Pasien yang memilki strategi koping yang tinggi akan membuat pasien patuh untuk menjalani terapi hemodialisis secara teratur. strategi koping pasien terhadap terapi hemodialisis adalah kesembuhan dan ingin kondisinya lebih baik dari sebelumnya. Setiap manusia mempunyai strategi koping, strategi koping tersebut tergantung pada pengetahuan, pengalaman, lingkungan hidup dan kemampuan masing-masing. Harapan pasien dalam menerima pelayanan medik adalah kesembuhan (Nursalam \& Kurniawati, 2007).

Penelitian ini didukung oleh penelitian yang dilakukan Kamerrer (2007) yang menunjukkan bahwa ada hubungan antara strategi koping dengan kualitas hidup pasien GGK menjalani hemodialisis. Hal ini disebabkan karena adanya keinginan yang tinggi untuk mencapai suatu tujuan yaitu agar sembuh dari penyakitnya. Pasien yang memiliki strategi koping tinggi 
cenderung patuh untuk melakukan hemodialisis dibandingkan dengan pasien yang memiliki strategi koping rendah. Hal ini disebabkan karena strategi koping merupakan salah satu faktor yang penting untuk meningkatkan kualitas hidup, karena strategi koping itu berasal dari dalam diri pasien.

\section{KESIMPULAN}

Berdasarkan hasil penelitian, pengolahan data dan pembahasan dapat disimpulkan:

1. Strategi Koping dengan kualitas hidup pada 79 pasien gagal ginjal kronis yang menjalani hemodialisa menunjukkan bahwa dari 79 pasien gagal ginjal kronis yang menjalani hemodialisa lebih dari setengah menggunakan strategi Problem Focused Coping (PFC) pada kategori sedang sebanyak 44 orang $(56,7 \%)$ dan sebagian besar memiliki kualitas hidup cukup sebanyak 39 orang $(88,6 \%)$. Berdasarkan penggunaan strategi Emotion Focused Coping (EFC) hampir setengah pasien gagal ginjal kronis yang menjalani hemodialisa adalah cukup sebanyak 36 orang $(45,6 \%)$.

2. kualitas hidup pasien gagal ginjal yang menjalani hemodialisa menunjukkan bahwa dari 79 pasien gagal ginjal kronis yang menjalani hemodialisa lebih dari setengah memiliki kualitas hidup cukup sebanyak 44 orang $(55,7 \%)$.

3. Hubungan strategi koping dengan kualitas hidup menunjukkan nilai probabilitas $(p)$ untuk strategi koping $=$ 0,000 , yang berarti ada hubungan secara signifikan dengan kualitas hidup $(p<0.05)$. Hasil analisis diperoleh nilai correlation coefficient $(\mathrm{r})=0,733$, menunjukkan hubungan yang kuat dan berpola positif artinya semakin tinggi penggunaan strategi Problem Focused Coping (PFC) maka kualitas hidup yang dimiliki pasien gagal ginjal kronis yang menjalani hemodialisa semakin baik, Sedangkan hasil analisis diperoleh nilai correlation coefficient $(\mathrm{r})=$ 0,419 , menunjukkan hubungan yang sedang dan berpola negatif artinya semakin rendah penggunaan strategi Emotion Focused
Coping (EFC) maka kualitas hidup yang dimiliki pasien gagal ginjal kronis yang menjalani hemodialisa semakin baik

\section{SARAN}

1. Bagi pelayanan kesehatan diharapkan dapat digunakan sebagai masukan bagi tenaga kesehatan untuk mengkaji dan memberikan pendidikan kesehatan kepada keluarga tentang strategi koping dan kualitas hidup pasien yang menjalani hemodialisa serta pentingnya kunjungan terapi hemodialisa secara rutin bagi pasien gagal ginjal kronik yang sedang menjalani terapi hemodialisa untuk menurunkan tingkat keparahan penyakit yang dialami pasien, sehingga klien termotivasi untuk rutin menjalani terapi dan dapat meningkatkan kualitas hidup pasien.

2. Bagi pendidikan keperawatan, hasil penelitian ini dapat dijadikan tambahan informasi yang berhubungan dengan hubungan strategi kopingidengan kualitas hidup pada pasien gagal ginjal kronis yang sedang menjalani pengobatan terpi hemodialisa.

\section{DAFTAR PUSTAKA}

Annas, J. (2010). Faktor-faktor yang mempengaruhi motivasi pasien gagal ginjal kronik untuk tetap menjalani hemodialisa di unit hemodialisa RS.Dr.Cipto Mangunkusumo. Materi dipresentasikan dalam PINTAS PAGI 2010. Diakses pada tanggal 05 Maret 2018.

Black \& Hawks.(2009). Medical surgical nursing clinical management for positive outcomes. $7^{\text {th }} \quad$ Edition. St.Louis: MissouriElseveir Saunders.

Chang, S. O [et.al]. (2003). Coping of patient undergoing hemodialysis. Asean Journal of Nursing Studies. 6, 40- 50.

Dani, R., Utami, G.T., \& Bayhakki. (2015). Hubungan Motivasi, Harapan, da Dukungan Petugas Kesehatan terhadap Kepatuhan Pasien Gagal Ginjal Kronik 
untuk Menjalani Hemodialisis. JOM Vol. 2 No. 2, Oktober 2015.Diakses tanggal 20 Juni 2018.

Da Silva, R.A.R., De Souza, V.L., De Oliveira, G.J.N., Da Silva, B.C.O., Rocha, C.C.T., \& Holanda, J.R.R. (2016). Coping Strategies Used by Chronic Renal Failure Patients on Hemodialysis. Escola Anna Nery 20(1) Jan-Mar 2016. Doi: 10.5935/1414-8145.20160020. Diakses tanggal 20 Juni 2018.

Folkman, S. (1985). Ways of coping questionare. University of California :. Sanfransisko.Diakses dari http://caps.ucsf.edu/uploads/tools/surveys/ ways\%20coping.pdf .Pada tanggal 04 Maret 2018.

Friedman, M.M., Bowden, R.V., \& Jones, G.E.(2010). Buku ajar keperawatan keluarga ; Riset, Teori, \& Praktik. (Edisi 5).Jakarta : EGC.

Garousi, S \& Garrusi, B. (2013).Does Perceived Family Support has a Relation with Depression and Anxiety in an Iranian Diabetic Sample. International Journal of Caring Science September-December 2013 Vol 6 Issue 3.Diakses tanggal 25 Juni 2018.

Gorman, L.M., \& Sultan,D.F. (2008). Pshycosoxial nursing for general patient care.(3th ed.). Philadelphia, F.A.: Davis Company.

Hays R.D., Kallich J.D., Mapes D.L., Coons S.J., Amin N., Carter W.B., \& Kamberg C. (1997). Kidney disease quality of life short form (KDQOLSFtm), version 1.3: A manual for use and scoring. Santa Monica, CA: RAND Health.

Ibrahim Kusman, Taboonpong, S., \& Nilmanat.(2009). Coping and Quality of Life among Indonesians Undergoing Hemodialysis.Vol. 13.No. 2. Thai J Nurs Res 2009; 13(2) 109-117. Diaksese tanggal 20 Juni 2018.

Ignatavicius, D., \& Workman, M.L.(2013). MEDICAL SURGICAL NURSING; Patient-Centered Collaborative care.Edisi 7.Buku 1. Elsevier Saunders.
Ismail., Hasanuddin., \& Bahar, B. (2012). Hubungan pendidikan, pengetahuan dan motivasi dengan kepatuhan diet pada pasien gagal ginjal kronik di Rumah Sakit Umum Pusat dr. Wahidin Sudirohusodo Makassar. Diperoleh tanggal 22 Maret 2015 dari http://library.stikesnh.ac.id/files/disk1/2/elibrary\%stikes\%20nani\%hasanuddinismail hasa -73-1-artikel-8.pdf.

Kaltsouda, A., et al., 2011.Defensive Coping and Health-Related Quality of Life in Chronic Kidney Disease: a Cross Sectional Study, BMC Nephrology, vol. 12, no. 28, hal. 1-9, (Online), http:// www.biomedcentral.com., Diakses pada tanggal 24 Desember 2011.

Kozier, B., Erb, G., Berman, A., \& Snyder, S.J. (2010).Buku ajar fundamental keperawatan: konsep dan praktik I (ed.7 vol.2). Jakarta: EGC.

Lase, W.N. (2011). Analisis Faktor-Faktor yang Mempengaruhi Kualitas Hidup Pasien Gagal Ginjal Kronis yang Menjalani Hemodialisa di RSUP Haji Adam Malik Medan.Diakses tanggal 15 Juni 2018.

Lianda, A.P. (2016). Motivasi Pasien Gagal Ginjal Kronik yang Dilakukan Hemodialisa di Raung Hemodialisa RSUD Kabupaten Jombang. Diak

Mc. Dowell, I. (2006). Measuring health: A guide to rating scales and questionnare, third edition. Oxford: Oxford University Press Inc.

Muhamad, M., \&Afshari, M., \& Kazilan, F.(2011). Family Support in Chronic Kidney Disease. Asian Pacific Journal Care Prev, 12, 1389-1397. Diakses tanggal 25Juni 2018.

Polit, D.F., \& Beck, C.T. (2012).Nursing research: Generation and assesing evidance for nursing practice $9^{\text {th }}$ Edition. Philadelphia, F.A.: Lippincott Williams \& Wilkins.

Rendy, C.M. \& Margareth, T.H. (2012).Asuhan keperawatan medikal bedah penyakit dalam. Yogyakarta: Nuha Medika. 
Sarafino, P.E., \& Smith, W.T.(2011). Health Psychology ; Biopsychosocial Interaction. Seventh Edition.Wiley.

Smeltzer, S.C., \& Bare, B.G. (2009).Buku Ajar keperawatan medikal bedah Brunner \& Suddarth. Edisi 8. Jakarta: ECG.

Son, Y.J., Cloi, K.Y., Park, Y.R., \& Bae, J.L. (2009).Depression, Symptoms and the
Quality of Life Patients on Hemodialysis for Life Patients on Hemodialysis for end Stage Renal Disease. American Journal Nephrology, 29, 36-42. DOI: 10.1159/000150599. Diakses tanggal 20 Juni 2018.

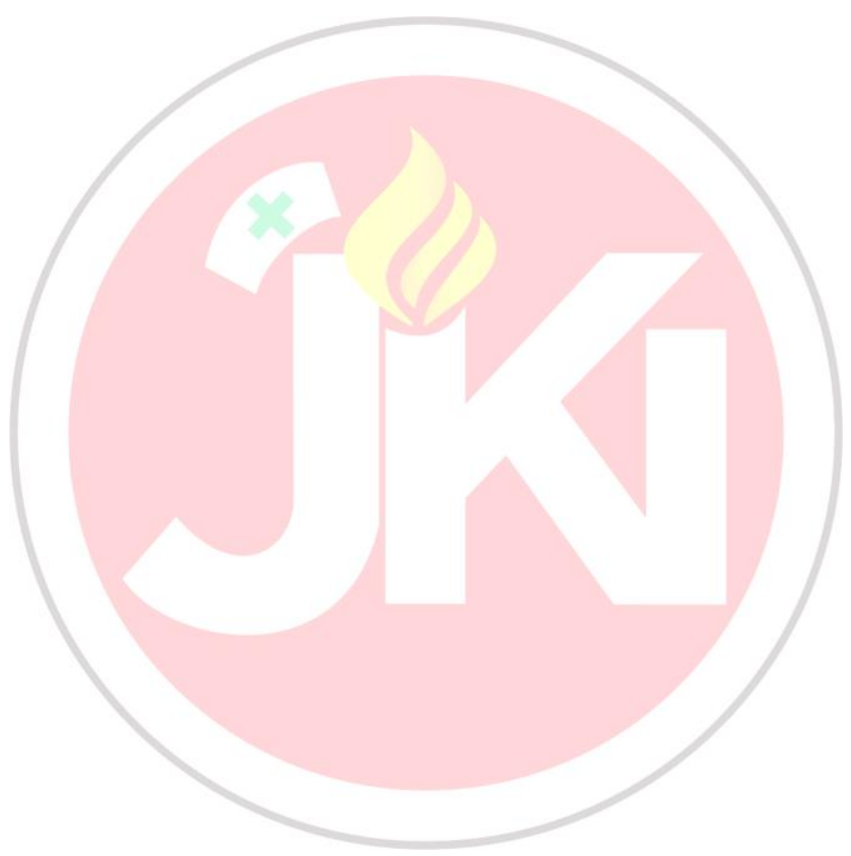

